\title{
An Exploration into Teachers' Perceptions towards the Challenges of Teaching Reading Skills using Communicative Language Teaching Approach: Focus on Wolaita Sodo Preparatory School
}

\author{
Tesfaye Buche Bosha ${ }^{1}$, Desalegn Youpo Ukute ${ }^{2}$ \\ ${ }^{1}$ Faculty of Social Sciences and Humanities Department of English Language and Literature Wolaita Sodo \\ University, Ethiopia \\ ${ }^{2}$ Faculty of Social Sciences and Humanities Department of English Language and Literature Wachemo \\ University, Ethiopia \\ Email : tesfayebuche@gmail.com
}

\begin{abstract}
:
The main purpose of this study is to explore teachers' perceptions towards the challenges of teaching reading skill using communicative language teaching approach: focus on Wolaita Sodo Preparatory School. Descriptive research design was employed. The data were collected through semi-structured interview and classroom observations. Six grade eleven EFL (English as a Foreign Language) teachers of the Wolaita Sodo Preparatory school were selected as of the study using convenience sampling method. The Interview data were tape recorded and transcribed into textual form and the classroom observation data were noted to analyze. The findings of this study disclosed that EFL teachers have a positive perception in towards teaching/reading skills using communicative language teaching approach but students were negatively perceived in learning/reading using Communicative Language Teaching (CLT). Hence, based on the findings, recommendations were made. In concurrence to this, the researcher recommends that the concerned bodies should give due attention to overcome selected problems which hampers teaching/reading skills using communicative language teaching approach particularly mobilizing EFL teachers through continuous capacity building activity is paramount.
\end{abstract}

Keywords :

perceptions, challenges; reading skills and communicative language teaching approach

\section{Introduction}

Reading provides the learners with a source of comprehensible input and serves to facilitate communicative competence in other language skills (Harmer, 2001). According to Borg (2003) teacher's perceptions regarding reading instruction through communicative language teaching is one of the most influential factor on what is done in classrooms and in the end on what students learn. There is now agreement in general in language education that teaching is a cognitive activity in which teachers' 'perceptions greatly impact their instructional decisions in the classroom (Harmer, 2001; Richards and Lockhart, 1997). Within second language education, teaching reading is also viewed as a complex cognitive activity (Borg, 2003). The same author advocates that teachers are active, and thinking decision-makers who make instructional choices by drawing on complex practically-oriented, personalized, and context-sensitive networks of knowledge, thoughts, and beliefsl (Borg, 2003:81). Irrefutably, research has indicated that teachers have a vast collection of complex beliefs about pedagogical issues including perception about teachers' and students' thought processes and classroom practices (Berliner, 1987; Borg, 2003; Burns, 2003; Richards and Rodgers, 2001).

These beliefs are whispered to form a structured set of principles and are derived from a teacher's prior experiences, school practices, and a teacher's individual perceptions (Borg, 2003). Furthermore, Hall (2005) suggested that what teachers do in the classroom is governed by what 
they perceive to work best and these perceptions often serve to act as filters through which instructional judgments and decisions are made. Borg (2003), Graves \& Aimonette,(2008), Singhall (2003), Farrell (2001), Breen, Hird, Milton, Oliver, \& Thwaite, (2001) point out that there is need to understand; and give account for the underlying belief systems of language teachers while teaching reading through CLT and the impact of these have on their classroom practices in order to improve instructive practices.

Some researchers point out that teachers have some problems in implementing CLT in ESL reading contexts such as teachers problems with the size of the classes as these classes are not large enough to implement reading by means of CLT, and most of the teachers are eager to take form based and knowledge based examinations which conflicts with the principles of CLT (Anderson, 1993; Li, 1998; Little wood, 2007; Liao, 2003). Cohen and Teller (1994) pointed out that perception of the teachers and students can play a very important role in their implementation of an approach, so teachers' and students' perception regarding the implementation of teaching reading via CLT can affect their practice too. Alemu (2004) investigated the importance of implementation of CLT by the teachers on the students interest in language learning in the context of Ethiopia, at the end of the research he came up with the conclusion that teachers' classroom practices in CLT can affect student's performance to a high extent; results of this study reflected this point that Ethiopian students are eager to do form based activities rather than communicative ones.

In understanding the language teacher by studying teachers' perception about reading instruction, Allen and Bruton, (1998) and Macaro (2006), reveal the knowledge that reading cannot be regarded as a set of perfunctory skills to be learnt. They point out that reading is a complex process of making meaning from a text for a variety of purposes and in a wide range of contexts. To a large extent in Ethiopia, reading in English is essential for learners' academic success because English is the medium of instruction in all formal settings put aside the other languages. However, in many situations where English is learnt as a second language (L2), learners usually experience the lack of reading strategies which are essential for them to read competently and overcome the challenges in the classroom when dealing reading within communicatively designed exercises, (Pressley, 2006; Beard, 1988; and Block and Pressley, 2002). Communicative language teaching approach was introduced as a main language teaching approach in our country Ethiopia before two decades. Conversely, the reading skill of high school students is not as expected at their level. For example; sometimes students fail to use basic words for communication and even they cannot express themselves clearly because of lack of reading proficiency.

Local research done by Surafel (2002) shows that large class size, in adequate background knowledge of the students, scarcity of textbooks, absence or scarcity of supplementary materials (for listening reading) and exam practice are some common problems English language teachers face while they are trying to implement the CLT approach. Amare (1998) in his article, 'Teachers' Perceptions of Educational Problems in Ethiopia,' has identified the following problems: overcrowded classes, shortage of instructional materials, heavy teaching loads, etc. He further mentions that teachers' attitudes are another source of problems in the teaching learning process in Ethiopia. So far, it seems that no research has been conducted about challenges of teaching reading skill using CLT in the Ethiopian context of language teaching and learning, and as a result of this, it is difficult to know what secondary school English language teachers perceive about communicative language teaching in EFL reading classroom. However, current research was intended to achieve teachers' perceptions related challenges in teaching reading using communicative language teaching approach at Wolaita Sodo Preparatory School. 


\section{Methodology}

It is said that research design is selected based on the purpose and nature of a research. The purpose of this study is identifying teachers and students allied challenges in teaching and learning reading skill using communicative language teaching approach. To achieve the purpose of this study, descriptive survey design was employed that includes both quantitative and qualitative techniques of data analysis. The activities to be performed in this study were descriptive in their nature. For this reason, descriptive research design was used to conduct this study.

This study was conducted at Wolaita Sodo Preparatory School. Currently, it has 450 male; 388 female students and totally 838 students; 4 male teachers, 2 female teachers (totally; 6 teachers) one principal. It has also vice academic and administrative principals and 8 administrative workers. Wolaita Sodo is located in South, Nations, Nationalities, and Peoples; Regional State, Wolaita Zone, Sodo city administration. It is located about $315 \mathrm{Km}$ away from Addis Ababa via Alaba direction. The major reason why the researcher selected this school to conduct his study is that the researcher observed that the extent to which communicative language teaching approach was used to teach reading was not yet studied.

In this study, EFL teachers and students of grade eleven were selected. There are six English language teachers in the selected school. All six English language teachers were selected for this study. Thus, it is believed that they can provide the data needed for this study as they can provide efficient data about the practices in the classroom. These six participant teachers have experience in the teaching of English as a foreign language. Their experiences range from one up to thirty years. Four of them are first degree holders in English language and the remaining two are M.A in TEFL.

The researcher was used all six EFL teachers using convenience sampling technique. This is because of they are convenient for this study. For interview the entire teachers who teach English were interviewed. Teachers were observed during teaching reading via communicative language teaching approach. To collect valuable and relevant data, two important instruments of data collection were employed. These are semi-structured interview and non-participant observation. These tools were developed primarily to meet the objectives of the study. Among the types of interview, the researcher employed semi-structured interview. The interview was developed primarily to meet the objectives of the study and to answer research questions.

\section{Discussions}

From the responses of the interviewees, it can be deduced that teachers' perception related challenges in teaching reading using communicative language teaching approach is one of the factor that affect teaching reading make use of CLT. These are: negative attitude towards CLT which means that most of the EFL teachers conceived that CLT solely focus on speaking rather than reading, lack of interest of students, shortage of textbooks, anxiety of language, loss of confidence in teaching reading using CLT in EFL class context, lack of preparation in teaching reading skill make use of CLT, teaching method is dominated by rule based which focus on grammar rather than communicative approach, mother tongue influence in teaching EFL reading class context, shortage of experience and poor class management.

This perception related challenge really confirmed by classroom observation context which means most of the EFL reading lessons were not observed when EFL teachers teaching reading 
using communicative language teaching approach. This implies that the EFL teachers of the School faced different challenges while teaching reading using CLT. It is profound that one's perception and attitude on certain arena can affect one's own practice of certain activities.

In the same logic, the perception of English language teachers' in teaching reading using communicative language teaching approach can have positive or negative impact on the extent to which they practice it. This finding of the study is confirmed by the previous findings of study. For example, Borg (2003), Grabe, (2004), Singhall (2001), Farrell (2001), Breen and Thwaite (2001),Hall, (2005) suggested that what teachers do in the classroom is governed by what they perceive to work best and these perceptions often serve to act as filters through which instructional judgments and decisions are made. Consequently, teacher related perceptions could affect teaching reading using CLT.

Finally, it is possible to say that there are factors that affect teaching reading using communicative language teaching approach. Some of the forwarded factors are: lack of instructional materials, inappropriate use of language teaching methodology and learning methods, negative attitude towards CLT, background knowledge, poor classroom management, lack of motivation, fail to use interactive activities, lack of training in teaching and learning using communicative language teaching approach in EFL reading classroom context, giving less attention when reading taught through CLT, misunderstanding between principles of CLT and teachers' practical engagement in teaching reading skills, native language affects foreign language teaching and students performance is the below the standard, textbook is not suitable to teach reading using CLT. Therefore, EFL teachers were facing different challenges in teaching reading using communicative language teaching approach. This was really revealed when the researcher observed the EFL teachers of the school teaching reading using communicative language teaching approach.

Four teachers observed for three times and totally the twelve reading lessons were observed what kind of challenges both teachers and students face when teaching and learning reading using CLT. In rejoinder to this each items were analyzed below:

Concerning item 1, the twelve reading teaching lessons were observed to see whether or not the English teachers afford bottom up approach when teaching reading skills. With regard to this, T1 and T3 afforded bottom up approach when teaching reading using different strategies such as reminding them meaning of each words, phrases and sentences. Further, T2 afforded when teaching reading using simply calling letters and symbols. Besides, T4 afforded bottom up approach using key words then defining them and giving activities how his students refer and infer activities which is taken from reading passage. This data obtained from classroom observation reveals that majority of teachers afford bottom up approach when teaching reading. Therefore, EFL teachers of the school afforded bottom up approach to teach reading skills.

With regard to item 2, T3 provided top down approach when teaching reading skills using varieties of tasks. On the other hand, T1, T2 and T4 were not observed when teaching reading skills providing top down approach. This implies that majority of teachers have gap in providing top down approach when teaching reading using communicative language teaching approach. Hence, the classroom data revealed that most EFL teachers of the school gave less attention for top down approach when teaching reading skills. In item 3, EFL teachers were observed to see whether or not they use inference when teaching reading skills. In retort to this, among the twelve reading lessons none of reading lessons were observed when they used inferences in teaching reading skills. The classroom data disclosed that most of EFL teachers of the school did not used inferences when they were teaching reading skills. 
In item 4, reading skills lessons were observed whether or not EFL teachers activate prior knowledge when teaching reading skills. With regard to this, almost all teachers of the school activated prior knowledge of their students when teaching reading skills. The result of the classroom data revealed that almost all teachers activate their students' prior knowledge when teaching reading skills. In item 5, twelve reading skill lessons were observed whether or not EFL teachers use reference questions when teaching reading. With regard to this, almost all EFL teachers of the school used reference questions when they were teaching reading. This implies that almost EFL teachers were using reference questions while teaching reading.

Again then in item 6, EFL reading lessons were observed whether or not teachers provide varieties of interactive activities when teaching reading. In riposte to this, none of the EFL reading lessons were observed when the EFL teachers were providing varieties of interactive activities when teaching reading make use of communicative language teaching approach. Henceforth, the classroom observation data disclosed that most of the EFL teachers were not providing varieties of interactive activities while teaching reading skills this is because of the lesson plan is not suits for teaching reading using varieties of interactive activities.

Concerning item 7, the EFL reading lessons were observed to see whether or not teachers of the School convey the interactive approach when teaching reading skills. With regard to this, none of the EFL reading skills lessons were observed when they were conveying interactive approach teaching reading skills. Therefore, almost all EFL teachers of the school did not conveyed interactive approach when teaching reading skills.

In item 8, T1 used task based instructions when teaching reading skills. He delivered different task based instructions such as varieties of tasks when he was teaching reading skills. In contrary to this, majority of EFL teachers of the School were didn't use task based instruction when they were teaching reading skills. The result of classroom observation disclosed that almost all EFL reading lessons were not observed when they were using task based instructions in teaching reading skills. This infers that most of the EFL teachers were not used task based instructions when they were teaching reading skills.

In item 9, reading lessons were observed whether or not EFL teachers use content based instructions when teaching reading skills using communicative language teaching approach. In rejoinder to this, most of the EFL lessons were not observed when they were using content based instructions to teach reading skills. Henceforth, the classroom observation result unveiled that most of the EFL teachers did not use content based instruction when teaching reading skills using communicative language teaching approach.

In item 10, EFL reading lessons were observed to see whether or not teachers deliver cooperative language learning approach to teach reading using communicative language teaching approach. In retort to this, T1 and T2 assigned students in group and giving different activities which is taken from the reading text. While as, T3 and T4 were not observed when they were teaching reading skills using communicative language teaching approach. Therefore, the result of the classroom observation revealed that half of EFL teachers of the school delivered cooperative language teaching approach when teaching reading skills using communicative language teaching approach.

In item 11, EFL reading lessons were observed to see whether or not the class size suitable for teaching reading using communicative language teaching approach. With regard to this, the researcher observed that class size is not suitable for teaching reading using communicative 
language teaching approach. Therefore, the class size of the school not suitable for teaching reading using communicative language teaching approach. This implies that all of the observed classes are overcrowded and the class is said to be large. The result of the observation disclosed that the class size is not suitable to teach reading make use of communicative language teaching approach in Wolaita Sodo Preparatory School context.

With regard to item 12, EFL reading lessons were observed to see whether or not teachers use authentic materials when teaching reading. In riposte to this, none of the reading lessons observed when EFL teachers were using authentic materials when teaching reading using communicative language teaching approach. This implies that all of the EFL teachers of the school used authentic materials when teaching reading using communicative language teaching approach. Thus, the result divulged that all of the EFL teachers of the school didn't use authentic materials when they were teaching reading skills.

In item 13, the researcher was observed the existing challenges of teaching reading using communicative language teaching approach. The observed challenges are: lack of knowing strategies of teaching reading using CLT, lack of prior knowledge, lack of experience in teaching reading using CLT, lack of enough space between chairs, tables and desks, lack of enough sitting materials, lack of textbook, large class size, lack of interest of students, loss of confidence, language anxiety and teaching method itself.

\section{Conclusions}

Based on the analysis of data in the previous sections, the researcher came up with the following conclusions.

The interview and classroom observation disclosed that almost all EFL teachers of the school believed that teaching reading using communicative language teaching approach is important to develop reading skill proficiency using communicative language teaching approach. This indicates that they were positively conceived teaching reading skills using communicative language teaching approach. As a result, they have no any perception related challenge in teaching reading using CLT. Nevertheless, the interview and classroom observation result disclosed that they were facing different challenges in teaching reading make use of communicative language teaching approach.

In conclusion, teachers' response on students' perception related challenges in teaching reading using CLT, the majority of teachers believed that EFL students of Belle Secondary and Preparatory School forwarded that there are challenges which impede students while teaching reading using communicative language teaching approach. For example, students' ability of learning reading using CLT into classroom context, interest related perception, shortage of textbook, lack of interest, large class size, shortage of sitting materials, shortage background knowledge, lack of practice, lack of motivation, negative attitude towards interactive activities, poor in comprehension skills, lack of contextualizing meanings, shortage of vocabularies, lack of grammar, lack of collaborative tasks and interactional nature of learning, lack of confidence, lack of awareness and less attention. 


\section{References}

Alemu H. (2004). An Evaluative Study of ELT Practice in Secondary Schools in Ethiopia: 2004 (Unpublished PhD dissertation).Hyderabad: Central Institute of English and Foreign Language.

Allen, J. and Bruton, A. (1998).Squeezing out the juice: Perceptions of reading in the Secondary School. Washington DC: Prentice hall.

Amare A. 1998. "Teachers' Perceptions of Educational Problems in Ethiopia." In Amare at al (eds.), Quality Education in Ethiopia: Visions for the 21stCentury Proceedings. Addis Ababa: IER.

Anderson, J.(1993). "Is a Communicative Approach Practical for Teaching English in China? Pros and Cons." System Vol.21 No.4:471-480.

Berliner, D.C. (1987). Simple views of effective teaching and a simple theory of Classroom Instruction. In D.C. Berliner \& B. Rosen shine (Eds.), Talks to teachers (pp. 93-110). New York: Random House.

Borg, S. (2003). Teacher Cognition in Language Teaching: A review of research on what Language teachers think, know, believe, and do. Journal of ELT vol. 36, No.5: 81-109.

Breen, M. P., Hird, B., Milton, M., Oliver, R., \&Thwaite, A. (2001).Making sense of language Teaching: Teachers' principles and classroom practices. Applied Linguistics, Vol.22 No.4:470- 501.

Burns, A. (2003, May). 'Developing reading skills: Current issues and teaching Suggestion' Workshop presented at the School of English and Applied Linguistics (SEAL), UNITEC, New Zealand.

Cohen, M.D., \& Teller, K (1994). Implementing cooperative learning for language minority Students. Bilingual Research Journal, Vol. 18, No 1:19.

Dorneyi, Z. (2007). Research Methods in Applied Linguistics. Oxford: Oxford U: Press

Farrell, T. S. C. (2001). Teaching reading strategies: „It takes time ". Reading in a Foreign Language, Vol.13:631-646.

Graves, M. F., \&Aimonette, L. L. (2008). Four facets of reading comprehension instruction in the middle grades. Middle School Journal, Vol.39: 36-45.

Hall, L. A. (2005). Teachers and content area reading: Attitudes, beliefs, and change. Teaching and Teacher Education, Vol.21,No.4: 403-414.

Harmer, J. (2001).The practice of English language teaching. New York: Longman Press.

Li, D (1998). It's always more difficult than you plan and imagine: Teachers' perceived Difficulties in introducing the communicative approach in South Korea. TESOL Quarterly,Vol.32: 677703.

Liao, X (2003). The need for Communicative Language Teaching in China. ELT Journal, Vol.58:270-273.

Little W. (2007). Communicative and task-based language teaching in East Asian classrooms. Language Teaching, Vol. 40, 2007, p 243-249.

Macaro, E. (2006). Strategies for language learning and for language use: Revising the theoretical framework. The Modern Language Journal Vol.90, No.3:320-337.

Pressley, M., \& Block, C. C. (2002). Summing-up: What comprehension instruction could? be. InC. C. Block, \& M. Pressley (Eds.), Comprehension Instruction (pp. 383-392). New York: Guilford Press.

Pressley, M. (2006).Reading instruction that works: The case for balanced teaching (3rded.).New York: Guilford.

Sarantakos, S. (2005). Social Research (Third edition). New York: Palgrave Mc Millen.

Singhal, M. (2003).Reading proficiency, reading strategies, Meta cognitive awareness, and L2 readers. The reading matrix, system Vol.31: 349-365. 
Surafel Z. (2002). "The Effects of the 'new' English Language Teaching Methodology in the First Cycle Secondary Schools." Educational Journal Vol.6 No.13: 70-86.

Richards, J.C. \& Rodgers, T.S. (2001).Approaches and Methods in language teaching Second Edition. New York, NY: Cambridge University Press.

Richards, J.C., \&Lockhart, C.(1997). Reflective teaching in second language classrooms. Cambridge: Cambridge University Press. 